\title{
404 トータルフロースクリューエキスパンダの基本特性
}

\section{理論効率の実用式}

Fundamental Performance of the Total Flow Screw Expander

Practical Expression of the Theoretical Efficiency

正 金子 達司（首都大） ○学 武部 良亮（首都大）

Tatsushi KANEKO. Tokyo Metropolitan University, Minami-osawa 1, Hachiouji, Tokyo Ryosuke TAKEBE, Tokyo Metropolitan University , Minami-osawa 1, Hachiouji, Tokyo

Key Words: Screw Expander, Energy Conversion, Geothermal Energy, Positive Displacement machine

\section{1. 墸钻}

近年のエネルギー消費量の增大やエネルギーの安全, 安定 供給問題に伴い, 自然エネルギーの積極的利用が求められて いる.中でも地熱エネルギーは我が国に豊富に存在する資源 であり，有効利用と進展が望まれている.スクリューエキス パンダは回転形の流体機械の特徵を備える一方で, 容積形の 作動原理を持つため, 湿り蒸気をそのまま利用するトータル フロー発電に有用であると期待されている(1).

前報(2)では，湿り蒸気を作動流体とし，適正膨張時におけ る内部圧力比と膨張比の関係を表わす実用式を提案した. こ れを用いることで適切な給気ポート設計を行うことができ る. 本報では実用式を用いた時のトータルフロースクリュー エキスパンダの理論仕事や理論効率を求め,これらにおよぼ す運転圧力比と蒸気の乾き度の影響について検討した。

\section{2. 迺正膨张}

漏えい損失や流動損失がなく，膨張過程で断熱膨張する理 想的なスクリューエキスパンダを仮定する. 膨張比 $\varepsilon_{i}$ はスク リューエキスパンダの基本設計パラメータで, この值により 給気ポートの形状が決定される. 作動流体が理想気体の時, 膨張比 $\varepsilon_{i}$ は次式より導かれる.

$$
\varepsilon_{i}=\lambda_{i}^{1 / k}
$$

ここで, $\lambda_{i}$ は内部圧力比(設計圧力比),$k$ は断熱指数である

Fig.1に理想スクリューエキスパンダの指圧線図を示す.条 件 $(\mathrm{i})$ では膨張終了時圧力 $P_{f}$ と排気圧力 $P_{d}$ が一致し，これを 適正膨張と呼ぶ. 条件( ii )では $P_{f}>P_{d}$ となり $\mathrm{g}$-c-h で囲む面積 が未回収仕事の損失となる.その結果，理論仕事 $W_{t h}$ は e-f-g-c-d で囲む面積で表される.

$$
W_{t h}=\frac{1}{k-1} P_{s} V_{s}\left(1-\lambda_{i}^{\frac{1-k}{k}}\right)+P_{s} V_{s}\left(1-\frac{\lambda_{i}^{\frac{1}{k}}}{\lambda}\right)
$$

ここで, $\lambda=P_{v} / P_{d}$ は運転圧力比を表す.

全断熱仕事 $W_{n d}$ は e-f-g-h-c-d の囲む面積で

$$
W_{a d}=\frac{k}{k-1} P_{s} V_{s}\left(1-\lambda^{\frac{1-k}{k}}\right)
$$

本研究では全断熱仕事 $W_{t d}$ と理論仕事 $W_{t h}$ の比を理論効率 $\eta_{t h}=W_{t h} / W_{t r l}$ と定莪する.

\section{3. 断熟指数の实用式}

作動流体が湿り蒸気の場合, 断熱指数 $k$ は乾き度によって 変化する.Fig.2に各乾き度における, 適正膨張時の内部圧力 比 $\lambda_{i}$ と膨張比 $\varepsilon_{i}$ の関係を示す. 本計算には蒸気表(3)を用いた. 直線の傾きが断熱指数に対応するが, 乾き度の低下の伴い減 少し，特に低乾き度で顕著である. 本結果より適正膨張におけ る断熱指数の值を乾き度の関数として,最小二乗法にて誤差 $0.1 \%$ の精度で多項式近似した実用式を(4)に示す.これは $x>0.75$ の断熱指数を近似したツオイナの値 ${ }^{(4)}$ とも一致する.

$$
\begin{aligned}
k(x)= & -7.8411 x^{6}+29.593 x^{5}-45.4216 x^{4} \\
& +36.621 x^{3}-16.839 x^{2}+4.5637 x+0.4507
\end{aligned}
$$

(4)式より適正膨張時の断熱指数が容易に得られ，(1)式を用い ることで作動流体を湿り蒸気とした場合にも適切な給気ポー ト設計を行うことができる.

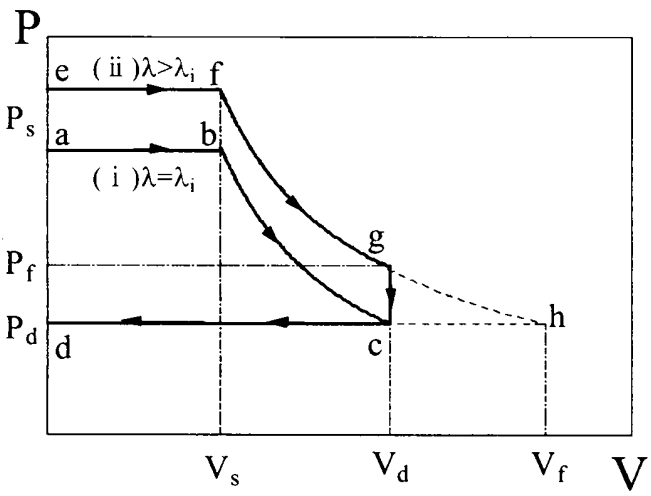

Fig.1 Indicator Diagram of Ideal Screw Expander

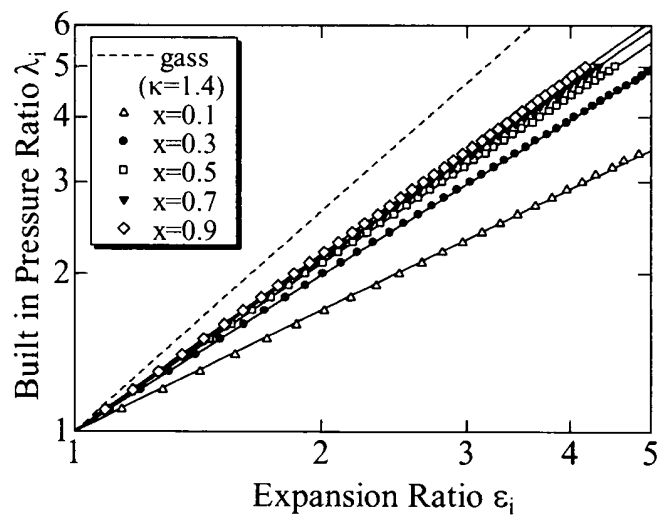

Fig.2 $\lambda_{i}-\varepsilon_{i}$ at Optimum Expansion 


\section{4. 理㰻仕事と理钴率}

湿り蒸気を作動流体とし，設計パラメータに乾き度を付 加した場合，理論仕事 $W_{t h}$ ，理論効率 $\eta_{t h}$ はそれぞれ次式で表 される.

$W_{t h}=\frac{1}{k(x)-1} P_{s} V_{s}\left[1-\lambda_{i}^{\frac{1-k(x)}{k\left(x_{i}\right)}}\right]+P_{s} V_{s}\left[1-\frac{\lambda_{i}^{\frac{1}{k\left(x_{i}\right)}}}{\lambda}\right]$

$\eta_{t h}=\frac{W_{t h}}{W_{a d}}=\frac{\left[1-\lambda_{i}^{\frac{1-k(x)}{k\left(x_{i}\right)}}\right]+[k(x)-1]\left[1-\frac{\lambda_{i}^{\frac{1}{k\left(x_{i}\right)}}}{\lambda}\right]}{k(x)\left[1-\lambda^{\frac{1-k(x)}{k(x)}}\right]}$

ここで, $x$ は運転乾き度, $x_{i}$ は設計乾き度である．

設計条件として内部圧力比 $\lambda_{i}=2.6$, 設計乾き度 $x_{i}=x$ とし， 運転压力比 $\lambda$ を変化させた時の理論仕事 $W_{\text {t }}$ を Fig. 3 に, 理論 効率 $\eta_{t h}$ を Fig.4に示す. 図中のシンボルは蒸気表から得られ た値, 実線は式(5), または式(6)を表し，両者は良く一致して おり, Fig.4 での誤差は最大で $1.0 \%$ 程度に収まっている. 内部 圧力比 $\lambda_{i}$ を固定し，運転乾き度に対応した設計乾き度でポー 卜設計を行った場合では， $\lambda=\lambda_{i}$ となる $\lambda=2.6$ で $\eta_{t h}=1$ となる が, 乾き度の低い蒸気ほど運転圧力比の変化に対する理論 効率の低下は大きい
次に設計条件を $\lambda_{i}=2.6, x_{i}=0.3$ とした時の理論仕事 $W_{\text {th }}$ を Fig.5に, 理論効率 $\eta$. を Fig.6に示す. 内部圧力比と設計乾き度 によって膨張比が固定され，運転乾き度が設計乾き度と異な る条件でも, 蒸気表から得られた值と実用式(4),(5)は良く一 致している.Fig.5 では運転乾き度の低下に対して理論仕事 $W_{\text {, }}$ は増加する.これは低乾き度の蒸気ほど膨張過程で指 圧線図の傾きが緩やかになり，回収仕事に対応する面積が 増加するためである. しかし Fig.6で示されるように低乾き 度では運転圧力比の増加に伴い, 未回収仕事に起因する損失 増加の影響が大きいため, 理論効率は大きく低下する.

\section{5. 結詇}

作動流体を低乾き度の蒸気とするトータルフロースクリ ユーエキスパンダの理論効率を断熱指数を用いて簡潔に表 す関係式を提案した.これを用いることで設計条件と運転 条件が異なる場合でも理論効率を容易に計算でき，損失の 解析や実験結果の検討に有用である.トータルフロースク リューエキスパンダは設計条件と異なる運転条件では理論 効率が低下する場合があり，運転条件の把握と適切な設計が 必要である。

\section{6. 考考文韵}

(1) R.F.Steidel,Jr., Journal of Engineering for Power, 104(2001), 231

（2）金子・他 1 名，機講論，NO.117-1(2011)，71

(3) SI 日本機械学会蒸気表

（4）谷下市松，工業熱力学基礎編，昭 60,184

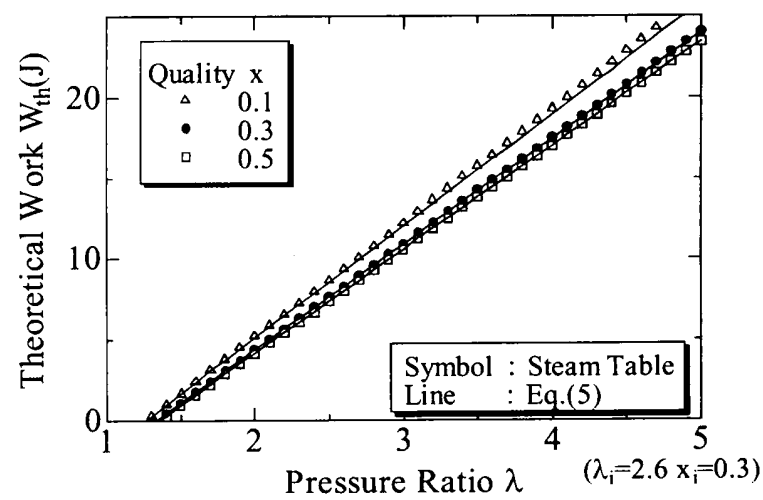

Fig.5 Theoretical Work

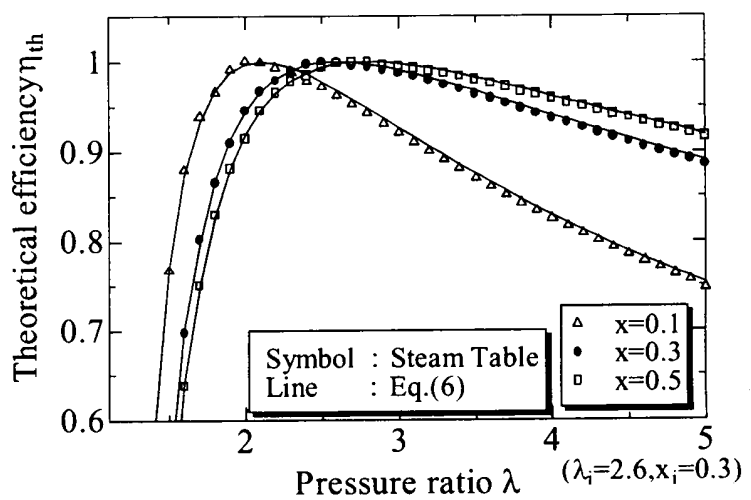

Fig.6 Theoretical Efficiency 